\title{
Extranodal Natural Killer/T-Cell Lymphoma: A Rare Nasal-Type Case
}

\author{
Ekstranodal Natural Killer/T-Hücreli Lenfoma: Nadir Bir Nasal Tip Olgusu
}

\author{
Esra Sarıbacak Can1, Harika Okutan1, Murat Albayrak1, Ünsal Han² \\ 1Dışkapı Yıldırım Beyazıt Research and Training Hospital, Clinic of Hematology, Ankara, Turkey \\ 2Dışkapı Yıldırım Beyazıt Research and Training Hospital, Clinic of Pathology, Ankara, Turkey
}

\section{To the Editor,}

Nasal type extranodal natural killer (NK) NK-cell/T-cell lymphoma (NKTCL) is a rare extranodal lymphoma of NK-cell or T-cell origin that most commonly affects immunocompetent middle-aged men of Asian or Native American descent [1]. The pathogenesis is not understood completely, but it is related in part to infection of the tumor cells with Epstein-Barr virus (EBV) [2]. Around 6-7\% of all non-Hodgkin's lymphoma (NHL) in Southeast Asia accounts for NKTCL. However, the incidence of $\mathrm{NHL}$ is lower in the United States at 1.5\% $[3,4]$.

Disease within the nasal cavity has a better prognosis. Radiation therapy alone can be curative. Over $60 \%$ of patients with stage 1 disease remain in long-term remission following treatment with radiation therapy with or without chemotherapy [5]. Nasal disease may be cured with radiotherapy at a rate of $85 \%$. However, the relapse rate is high at $25 \%$. Therefore, it is highly crucial for this aggressive disease to be diagnosed and treated at an early stage $[6,7]$.

In our case, a 29-year-old female complained of nasal obstruction and had a necrotizing mass in the upper middle concha at the right nasal cavity; biopsy was planned. CD56 was strongly positive (Figure 1), CD8 was positive in a few scattered cells, and CD4 was positive in the majority of infiltrating $T$ cells in the sample of necrotic tissue pieces. TIA-1 and perforin were commonly positive. Granzyme was commonly strongly cytoplasmic-positive. Epstein-Barr encoding region (EBER) in situ hybridization analysis was done with a probe cocktail containing EBV. Early RNA transcript showed that NKTCL compatibility existed with commonly strongly nuclear-positivity in EBER infiltrating cells. Positron emission tomography-computed tomography (PET-CT) revealed pathologically heterogeneous soft tissue mucosal thickening, pushing the nasal septum slightly to the left and hypertrophy of the right ethmoid cells in the upper middle concha level of the nasal cavity, with increased metabolic uptake $\left(\mathrm{SUV}_{\max }: 3.18\right)$. The patient was diagnosed with stage $1 \mathrm{E}$ based on PET-CT evaluation and received a total of 38 Gy external radiotherapy at 200 cGy daily. No involvement was detected month after radiotherapy and complete response was considered to have occurred after 1 year.

NKTCL of the palate and sinuses has been reported in many cases. However, the incidence of NKTCL is much lower in the United States. Nasal obstruction, bleeding, pain, or local swelling are usually observed and ulcerative, destructive lesions within extranodal sites can be produced. Often it is associated with EBV. Immunophenotypically, the tumor cells express CD2, CD3, and CD56. The cells can lack CD56 and express CD8+ T-cell antigens in some cases [7]. The course of NKTCL, nasal type, is aggressive where a 5 -year overall survival ranges from $25 \%$ to $50 \%[8]$.

Symptoms of nasal type NKTCL can include nasal discharge, nasal obstruction and other nonspecific sinonasal symptoms. However, sore throat and dysphagia, also known as symptoms of nasal type NKTCL, are frequently missed and treated as viral and bacterial pharyngitis, which leads to late diagnosis. Therefore, morbidity and mortality are increased. NK/T-cell lymphoma, nasal type, is rarely observed in Turkey and early diagnosis of the disease is of vital importance.

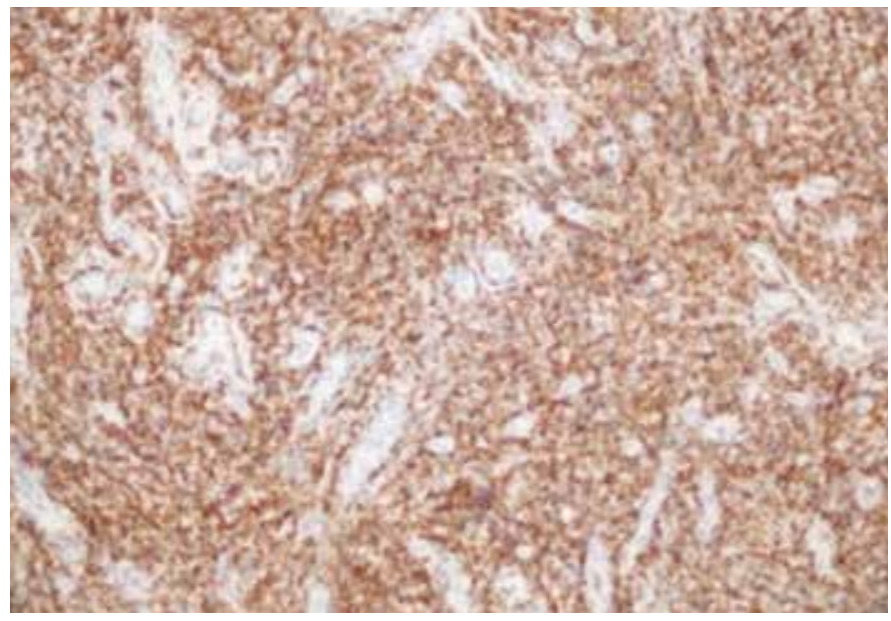

Figure 1. Strong staining of diffuse cytoplasmic natural killer cells with CD56 (CD56, IHC, 200×). 
Keywords: Extranodal natural killer/T-cell lymphoma, NonHodgkin lymphoma

Anahtar Sözcükler: Ekstranodal natural killer/T-hücreli lenfoma, Hodgkin dışı lenfoma

Authorship Contributions

Concept: Esra Sarıbacak Can, Design: Esra Sarıbacak Can, Data Collection or Processing: Esra Sarıbacak Can, Analysis or Interpretation: Esra Sarıbacak Can, Harika Okutan, Literature Search: Esra Sarıbacak Can, Murat Albayrak, Writing: Esra Sarıbacak Can, Ünsal Han.

Conflict of Interest: The authors of this paper have no conflicts of interest, including specific financial interests, relationships, and/or affiliations relevant to the subject matter or materials included.

\section{References}

1. Roschewski M, Wilson WH. EBV-associated lymphomas in adults. Best Pract Res Clin Haematol 2012;25:75-89.

2. Niedobitek G. Epstein-Barr virus infection in the pathogenesis of nasopharyngeal carcinoma. Mol Pathol 2000;53:248-254.

3. Al-Hakeem DA, Fedele $\mathrm{S}$, Carlos R, Porter S. Extranodal NK/T-cell lymphoma, nasal type. Oral Oncol 2007;43:4-14.

4. Jaccard $A$, Hermine 0 . Extranodal natural killer/T-cell lymphoma: advances in the management. Curr Opin Oncol 2011;23:429-435.

5. Liu QF, Wang WH, Wang SL, Liu YP, Huang WT, Lu N, Zhou LQ, Ouyang $\mathrm{H}_{\text {, }}$ Jin J, Li YX. Immunophenotypic and clinical differences between the nasal and extranasal subtypes of upper aerodigestive tract natural killer/T-cell lymphoma. Int J Radiat Oncol Biol Phys 2014;88:806-813.

6. Liang R. Diagnosis and management of primary nasal lymphoma of T-cell or NK-cell origin. Clin Lymphoma 2000;1:33-38.

7. Hasserjian RP, Harris NL. NK-cell lymphomas and leukemias: a spectrum of tumors with variable manifestations and immunophenotype. Am J Clin Pathol 2007;127:860-868.

8. Kwong YL. Natural killer-cell malignancies: diagnosis and treatment Leukemia 2005;19:2186-2194.

\title{
T-Cell Lymphoma Presenting with Auricular and Parotid Gland Involvement
}

\author{
Aurikula ve Parotis Bezi Tutulumu ile Seyreden T-Hücreli Lenfoma
}

Birgül Öneç¹, Alper Koç2, Elif Nisa Ünlü3, İlhan Ünlü4 ${ }^{4}$ Hüseyin Yaman4, Durdu Mehmet Köş2

${ }_{1}$ Düzce University Faculty of Medicine, Department of Hematology, Düzce, Turkey

${ }^{2}$ Düzce University Faculty of Medicine, Department of Internal Medicine, Düzce, Turkey

${ }^{3}$ Düzce University Faculty of Medicine, Department of Radiology, Düzce, Turkey

${ }^{4}$ Düzce University Faculty of Medicine, Department of Otorhinolaryngology, Düzce, Turkey

To the Editor,

The external auditory canal is an unusual presenting site for lymphomas, with only a few case reports in the literature $[1,2]$. Malignant lymphomas arising from the salivary glands are also uncommon, accounting for approximately $5 \%$ of extranodal lymphomas, and the majority of them are of B-cell lineage. Primary salivary gland T-cell lymphomas are extremely rare $[3,4,5]$.

A 63-year-old man was admitted with swelling of the left side of his face and left auricle. Considered as an infection, it was empirically treated with systemic and topical antibiotics. Examination by an otorhinolaryngologist revealed a suppurative lesion that consisted of ulcerated areas and granulation tissue in the external auditory canal and preauricular region in addition to edema (Figure 1A). A lobulated mass lesion of 47x39 mm arising from the left parotid and extending to the left auditory canal was detected in computed tomography (CT) with accompanying lymph nodes in the left subauricular and cervical localization. Fine-needle biopsy was nondiagnostic and incisional biopsy found only severely active chronic inflammation. Finally, deep excisional biopsy revealed CD3-, CD5-, and CD30-positive and S100-negative lymphoid cells diffusely infiltrating the dermis. The case was considered as stage 2 peripheral T-cell lymphoma not otherwise specified peripheral T-cell lymphoma-not otherwise specified (PTCL-NOS) and CHOP (cyclophosphamide, 